\title{
Maritime Archaeology in Finland: History and Future Tasks
}

\author{
Marko Marila $^{1}$ (D) Kristin Ilves $^{1}$ (D)
}

Received: 17 February 2021 / Accepted: 19 May 2021 / Published online: 3 June 2021

(c) The Author(s) 2021

\begin{abstract}
This article provides an account of the history, present state, and possible future directions of Finnish maritime archaeology in order to elucidate certain aspects characteristic of the field. In the Finnish context, academia and the heritage sector are historically interconnected, and professionals have successfully assumed responsibilities in both. Research opportunities, however, have been more numerous at the Finnish Heritage Agency (FHA) than in academia, whereas the focus has been on well-preserved wrecks mainly from seventeenth and eighteenth centuries. This can be explained by the great number of registered shipwrecks from the historical periods being managed by the FHA. Well-preserved shipwrecks are also central for hobby divers' interest that has been historically paramount for the development of the field. At the same time, discontinuities in academic training of maritime archaeologists have created a situation where opportunities for long-term and indepth research at universities have been few. Future prospects of Finnish maritime archaeology are discussed with respect to the current state, and the interconnectedness of the heritage management sector, academically trained maritime archaeologists, and avocational diving societies and volunteers is emphasised as a key element in continued development.
\end{abstract}

Keywords Finnish maritime archaeology $\cdot$ Heritage management · Higher education · History of maritime archaeology $\cdot$ Hobby diving $\cdot$ Shipwrecks

\section{Introduction}

Archaeology in Finland-terrestrial and maritime-shares a close history with the development of cultural heritage management. Academic tasks, i.e., at the University of Helsinki, where archaeology has been taught since the late 1870s, and those falling under the category of heritage management, most notably handled by the Finnish Heritage Agency (hereinafter FHA), the central organization responsible for the protection and management of cultural heritage in Finland, were largely shared until the 1960s. However, heritage management and academic research began to diverge from one another with the

Marko Marila

marko.marila@helsinki.fi

Kristin Ilves

kristin.ilves@helsinki.fi

1 Department of Cultures, University of Helsinki, Helsinki, Finland 
implementation of the Antiquities Act in 1963 and the establishment of teaching in archaeology at the University of Turku and the University of Oulu in the 1960s (Immonen and Taavitsainen 2011; Immonen 2016).

With the divergence of heritage management and research, the tasks of heritage management were now clearly directed toward monitoring, protecting, maintaining, preserving, and making decisions about ancient monuments, while research was no longer carried out within that framework and was instead conducted at the universities. While this led to increased opportunities for archaeological research related to heritage on land, the same was not the case with maritime, especially underwater, archaeology. This is partly explained by the lack of diving researchers. The teaching of maritime archaeology in Finnish higher education did not emerge until the early 1990s, and between the 1960s and the 1990s Finnish underwater heritage management was totally dependent on volunteer hobby divers. The close ties between heritage management and hobby divers were forged during those early formative decades, and today Finnish maritime archaeology continues to rely heavily on the input of avocational diving societies and individual volunteers.

The field of maritime archaeology in Finland is still quite small. Only one permanent position exists in the academic sphere, while the number of people working in maritime archaeology and underwater cultural heritage protection at the FHA is five. In addition, one person holds a permanent position in maritime heritage management on the Aland Islands, an autonomous region of Finland. Doctoral and postdoctoral projects in academia, currently more numerous than ever before, as well as large-scale fixed-term projects at the FHA, also offer employment opportunities. The majority of people actively involved in research and heritage management today received their training and field expertise in the 1990s and the first decade of the 2000s, the latter period marking somewhat of a high season for maritime archaeological research at the FHA in terms of available funding and engaged personnel. Research projects carried out in those decades were often organized as collaborative efforts between the FHA and hobby divers, and much of the knowledge about underwater heritage in the northern parts of the Baltic Sea was produced as a result of those collaborative projects.

While significant advances have occurred in maritime archaeological research since the 1960s, mostly through projects organized by the FHA, research opportunities have gradually diminished within the organization, increasingly so after an organizational restructuring in 2011. Whereas a number of large maritime archaeological research projects including underwater excavations were organized within the FHA until the 2000s, research has not been the focus of the institution in more recent times. Projects organized at the FHA today are targeted at producing solutions for the recreational and developmental use of the Baltic Sea areas and the maritime heritage of the Baltic Sea rather than investigations leading beyond documentation and identification. This development is in line with the FHA's role as the enforcer of Finnish heritage legislation.

Because research within the heritage management sector is mainly motivated by protection and management of underwater cultural heritage, research responsibilities are also expected to be fulfilled by academia. Unfortunately, however, higher education in maritime archaeology in Finland has been quite marginal compared to terrestrial archaeology. While modules including or consisting of courses devoted to maritime archaeology have sporadically been taught at the University of Helsinki and the University of Turku since the early 1990s, maritime archaeological research done in academia has been scarce. For instance, regardless of how encompassing one is in defining maritime archaeology, less than a handful of doctoral dissertations on the topic have been defended in Finland thus far (Tuovinen 2002; Koivikko 2017; Koivisto 2017). Since no master's degree programme in maritime 
archaeology currently exists in the country, future prospects for academic research seem bleak.

The purpose of this article is to critically contribute to understanding of the state of maritime archaeology in Finland. In order to elucidate aspects characteristic of the field, in particular those raised above, we provide a thorough overview on the development of the discipline in light of significant discoveries and methodological developments as well as the interconnectedness of academic maritime archaeology, heritage management, and avocational diving. In addition, we provide a history of maritime archaeology teaching in Finnish universities and reflect on the present field of maritime archaeological expertise in the country as well as on the role of higher education in securing opportunities for maritime archaeological research in the future.

\section{Previous Historiographical Research}

Research history within the field of maritime archaeology is often dealt with as part of more specific research on particular sites or research methods, and more general overviews of the development of the field are singular. Furthermore, there is a tendency to focus more attention on the introductory phases of the discipline's formation (e.g., Immonen 2016; Koivikko 2017). Three brief accounts of Finnish maritime archaeology, by Nils Cleve (1961), Ora Patoharju (1962), and Juhani Peltonen (1964), were written at a time when the discipline was just about to take form, whereas a subsequent account by Henrik Rosenius (1983) likewise looks back exclusively at those early years. Rosenius divides the early history of Finnish maritime archaeology into three periods: an initial phase, in the years 1935-1950, with only a few research projects that are best described as experimental; the first phase, between 1951 and 1960, when the number of research projects numbered in the dozens and when collaboration between archaeologists and hobby divers first began; and the second phase, from 1961 to 1965, with there being a significant increase in the number of research projects after 1962. Rosenius ends his overview in the year 1965, which indicates that, in his opinion, this can be seen as marking the end of the pioneering phase of Finnish maritime archaeology. This synchronizes with international understanding of the field's divisions and early phases of development (Barstad 2002).

It took more than 30 years before the development of Finnish maritime archaeology was once again included in historiographical treatments of the field. Visa Immonen (2016, 252-259) provides a concise, combined history of maritime archaeology and underwater heritage management in his historiography of the FHA between 1917 and 1972, but this overview is necessarily narrow in focus and also limited to the early years. Similarly, a brief introduction to the development of underwater research in Finland was recently provided by Minna Koivikko (2017, 17-22), but that too ends with the 1970s, and in fact Koivikko states that a detailed study of the history of Finnish maritime archaeology remains to be written.

The early history of Finnish maritime archaeology, as presented in the few existing historiographical overviews, is intimately connected to the management of underwater heritage. However, our examination has found that the subsequent development of maritime archaeology is also deeply intertwined with heritage management. A closer look at the history bridging the early years and the current situation reveals an unwavering state of interconnectedness of heritage management and research in maritime (underwater) archaeology. Furthermore, the role of the avocational diving community as an important stakeholder in 
management and protection, but also research, continues to be central, while universities play a sporadic role.

\section{Maritime Archaeology and the Establishment of Underwater Cultural Heritage Management}

The professionalization of maritime archaeology in Finland is intimately tied to the history of the FHA, the largest governmental organ responsible for the protection of cultural heritage since the $1880 \mathrm{~s}$. As in many other countries, the common history of maritime archaeology and state-led heritage management starts no earlier than the mid-1900s with the increasing discovery of shipwrecks, mostly as a result of the technological advances related to diving equipment (Cleve 1961; Rosenius 1983). Some discoveries have had an important role in shaping the development of the field worldwide (e.g., Delgado 2000; Barstad 2002; Broadwater 2002). In terms of similarly important discoveries, the shared history of Finnish maritime archaeology and underwater heritage management can be said to have begun in the 1960s with the investigations of the Russian frigate St. Nikolai that sunk in 1790 during the Battle of Svensksund, close to the present-day city of Kotka in south-eastern Finland.

The wreck of St. Nikolai, although originally identified as the frigate St. Maria (Cleve 1961, 351), was discovered already in October 1948, and salvage was attempted by a German team in 1949, with destructive effects. Reflecting on the event, Christoffer Ericsson $(1972,174)$ laments that "[h]ere ended the sad story of amateurish trial and error". Serious research on the site started in the early 1960s, and St. Nikolai became central to the methodological development of the discipline in Finland (Cleve 1961; Rosenius 1968; 1983; Ericsson 1972, 1975; Halme 1977; Sarvas 1977; Sorvali 1977; Mattsson 1990). The wreck became the first in Finland to be systematically documented as a collaborative effort between hobby divers and FHA archaeologists. In addition to drawing, underwater photography, photogrammetry, and $8 \mathrm{~mm}$ underwater filming (Fig. 1) were quickly adopted as documentation methods for St. Nikolai as well as other sites discovered in those early years (Ericsson 1970; Johnsson 1988). Many finds were lifted from the wreck after its discovery, although with little regard for their contextual information or for the ship's constructional

Fig. 1 Hobby diver Kalervo Karalahti loading an 8-mm-film camera into its underwater casing during the St. Nikolai investigations in 1972. Photographer unknown. Collections of the Maritime Museum of Finland (CC BY 4.0)

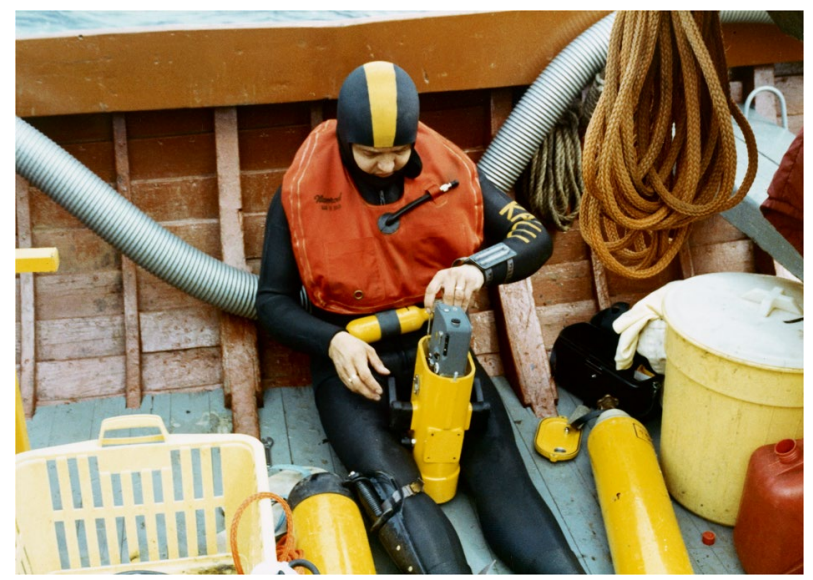


elements. While a great number of finds were lost forever due to non-existent conservation methods, some finds from St. Nikolai, especially cannons, grenades, and round shots (Fig. 2), also benefitted from the first successful experiments with chemical conservation by chemist and hobby diver Ora Patoharju (1965; 1975). Finds from St. Nikolai were exhibited in 1970 in the city of Kotka, and in 1971 at the Amos Anderson Art Museum in Helsinki (Ericsson and Halme 1971).

Another early discovery important for the development of maritime archaeology in Finland was the so-called Borstö I wreck in Parainen, in south-western Finland, discovered in the 1950s (Cleve 1961; Nurmio-Lahdenmäki 2005; Ehanti et al. 2012). This mideighteenth-century wreck was the site of Finnish-Swedish diving collaboration in the early 1960s. In 1961, close to 200 artefacts were lifted from it, including dozens of gold and silver watches and snuff boxes and a horse-drawn carriage (G. Bojner 1965, unpublished research report for the FHA). Some of the finds lifted from the water were exhibited at the National Museum of Finland in the spring of 1962 (Peltonen 1964). This may have been the first maritime archaeological exhibition organized at the National Museum, and the venue was chosen because it had an advanced alarm system to safeguard the precious gold and silver finds (Talvio 2016, 242). In 1995, equally valuable Meissen porcelain tableware was found in the wreck (Hyvönen 1997). The Borstö I wreck was first identified by Christian Ahlström (1978, 60-64) as St. Michel, and it appears in Finnish literature under that name, but subsequent research suggests that the wreck may not have been accurately identified (Alvik 2013; Kaukiainen 2020).

As important as the early research on wrecks such as St. Nikolai and Borstö I since the early 1960s was for the development of maritime archaeology and underwater heritage management in Finland, the increasing popularity of sports diving was equally significant

Fig. 2 A round shot lifted from the St. Nikolai most likely in the early 1960s. The iron ball was conserved and encased in plastic by Ora Patoharju in 1963. Photographer unknown. Collections of the Maritime Museum of Finland (CC BY 4.0)

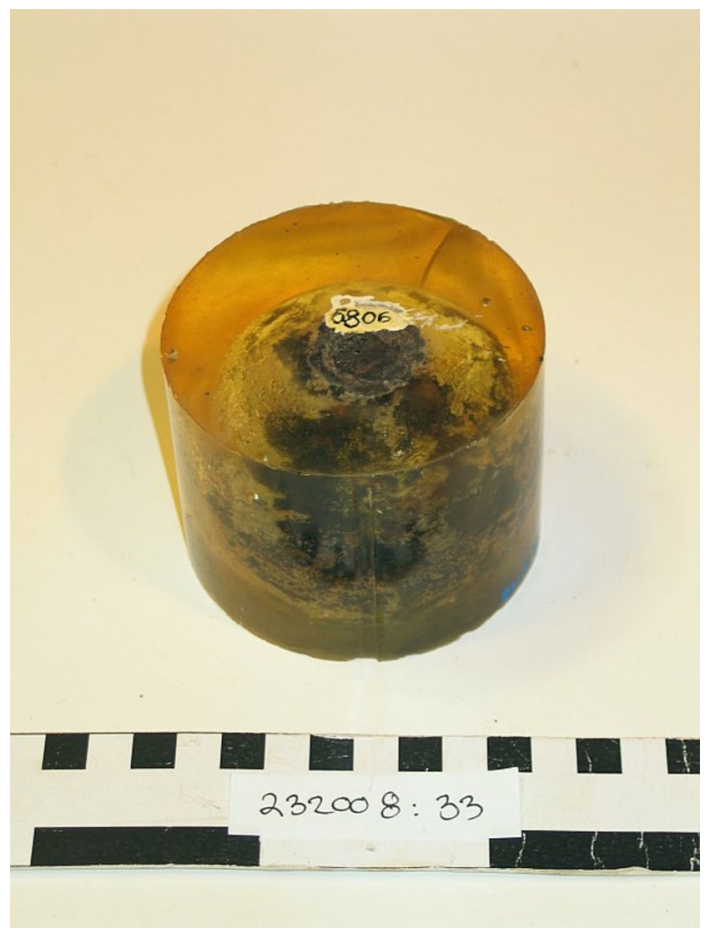


(Halme 1976). The discovery of St. Nikolai in particular received a fair amount of attention in the media, which, coupled with the spectacular raising of the Swedish warship Vasa in 1961, led to an increase in public interest in locating and exploring underwater sites in Finland. As pointed out by Henrik Rosenius $(1983,20)$ in his account of the early decades of Finnish maritime archaeology, between 1961 and 1965 the number of known wrecks increased so much that it became impossible to compile a detailed list of all sites and divers' activities on them. Activities centred around the growing number of discovered wrecks and the increasing amount of material lifted from them by individual hobby divers as well as archaeologist-led research projects were problematic from a museological point of view, namely because Finland lacked both the expertise and infrastructure to manage the findings. This actively advanced discussions that had already begun in the 1950 s about the establishment of a national maritime museum that could facilitate the research and management of the growing amount of wreck-related material (Cleve 1976, 8-9; Heikkinen 1976; Talvio 2016, 287-290).

Concrete attempts at founding a centralised maritime museum were made in the early 1960s. In 1962, as a result of an initiative made by the FHA, the Finnish Ministry of Education appointed a committee to prepare the establishment of a national maritime museum (unpublished maritime museum committee report, 30 December 1963). While ambitious, the committee statement did not lead to the formation of such a museum. The main reason for the negative decision was that the FHA was not unanimous in its discussions about the museum's establishment; infrastructural problems also existed with the planned location on the island of Suomenlinna (Cleve 1976, 10-11). In 1963, as a result of the disappointment caused by the failed plans, the Finnish Association for Maritime History (called the Maritime Museum Association until 1975) was founded by maritime museum actives to continue to advance the plan for establishing the museum (Koistinen 1976).

In 1964, Helge Jääsalo, then director of Finnish Maritime Administration and member of the maritime museum committee, proposed the maritime pilots' barracks on the island of Hylkysaari in Helsinki as a future location for the museum (Hyvärinen and Sammallahti 1991; Fast 1996; Immonen 2016, 256; Talvio 2016, 288). As result, the maritime museum committee convened for the second time in 1964 (unpublished maritime museum committee report, 31 March 1965). Again, regardless of the committee's suggestion to establish a maritime museum at the proposed location, the Ministry of Education decided not to follow through with the project.

However, the plans for the museum, leading to its subsequent foundation in 1981, were kept alive by theestablishment of the Bureau of Maritime Archaeology (later the Bureau of Maritime History), which was established partly as a compromise on the failed plans for a maritime museum and partly as a reaction to the legal responsibilities imposed on the FHA by the Finnish Antiquities Act (295/1963). With the act, which was put into effect in 1963, all ships that had sunk more than 100 years ago — as well as any loose finds associated with them-were brought under legal protection for the first time in the history of Finnish heritage management. Motivated by the growing number of hobby divers and activities around known underwater sites, as well as by the legal responsibilities introduced by the Antiquities Act, the Bureau of Maritime Archaeology was founded by the FHA in 1968. It would become the responsibility of the bureau to enforce the Antiquities Act as pertains to underwater sites (unpublished 1968 annual report of the FHA), but also to undertake maritime archaeological and maritime historical research.

Research conducted by the bureau has been published in its series The Bureau of Maritime Archaeology/History Report between 1969 and 1975, in The Maritime Museum Helsinki/Finland Annual Report since 1976, and as part of the Nautica Fennica series since 
1976. Nautica Fennica was established as a joint publication of the bureau and the Finnish Association for Maritime History, but it has since developed into a general publication series for research in maritime archaeology, maritime ethnology, and maritime history. This is also reflected in the topics of published research. Whereas the great majority of publications deal with wrecks and their material culture, as well as with maritime history, the 2000s has seen an increase in maritime ethnology and, for example, research focused on matters of gender therein. This is also indicative of the diminishing importance of Nautica Fennica as a maritime archaeological forum, whereas the original purpose of the series was to serve as a publication for research conducted by the bureau.

Organizationally, the Bureau of Maritime Archaeology was placed directly under then state archaeologist and director of the FHA, Nils Cleve, while Christoffer Ericsson was appointed as the leader of the bureau (Cleve 1976). Cleve, who was also leader of the maritime museum committees, had an interest in underwater archaeology and maritime history. His importance to the development of Finnish maritime archaeology is highlighted by the fact that in 1975, one of the FHA's larger research vessels was named after him (Immonen 2016, 254-255).

The Bureau of Maritime Archaeology was supposed to be a temporary organization, but with the organizational restructuring in 1972, it was made a permanent part of the FHA's research department, only now its name was changed to Bureau of Maritime History (Cleve 1976, 12; Talvio 2016, 287). In the autumn of 1973, the bureau was relocated to the then newly renovated barracks on Hylkysaari. This facilitated the building of permanent exhibitions at the site, and after decades of planning, the Maritime Museum of Finland was finally opened to the public in 1981 (Fig. 3). The museum has always been part of the National Museum of Finland, which in turn is organizationally part of the FHA, as had been the Bureau of Maritime History.

The Maritime Museum was open for 23 years before it was temporarily closed in 2004 after the Ministry of Education decided to move the museum from Helsinki to the town of Kotka (Ministry of Education 2004). The museum's relocation was motivated by a growing need for larger premises, and despite opposition by the museum staff, Kotka was chosen as the new location over Turku or Helsinki. In 2008, the museum reopened to visitors in the newly built Maritime Centre Vellamo building (Fig. 4; Aartomaa 2008; Suhonen 2009; Utriainen 2010). With these changes came

Fig. 3 The Maritime Museum of Finland opened to the public on May 18, 1981, in an old maritime pilots' barrack on the island of Hylkysaari in Helsinki. The ship is the icebreaker Tarmo, restored into a museum ship in the early 1990s and currently kept at the Maritime Centre Vellamo in Kotka, Finland (see also Fig. 4). Photo: Timo Syrjänen (1981). Collections of the Maritime Museum of Finland (CC BY 4.0)

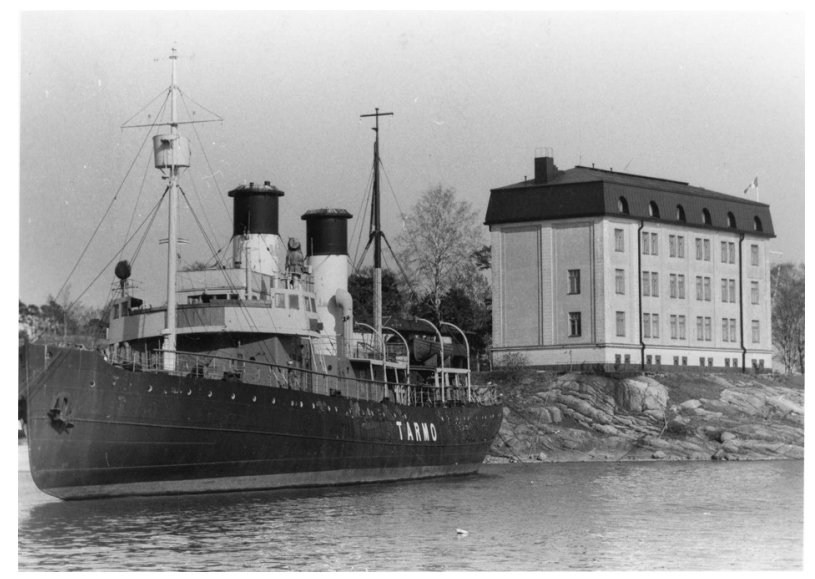


Fig. 4 Since 2008, the Maritime Museum of Finland has operated in the Maritime Centre Vellamo building in Kotka, Finland. Main entrance is from the south, but the wavelike form of the building is most striking when viewed from the northern facade. Photo: Marko Marila (2020)

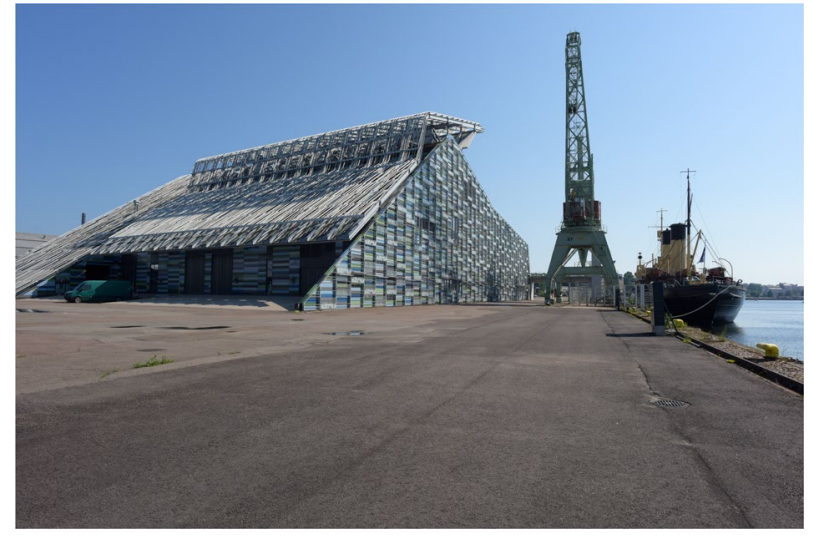

also organizational updates. With the relocation of the museum, heritage management tasks were separated from museum work. Also, the Bureau of Maritime History was closed in 2004 and the newly established Maritime Archaeology Unit, now separated from its history with the Maritime Museum, was placed organizationally under FHA's Archaeology Unit. The establishment of the Maritime Archaeology Unit marked the beginning of a high season in Finnish maritime archaeology and underwater heritage management, lasting from 2004 to 2011. The Maritime Archaeology Unit remained on Hylkysaari, it had a staff of approximately ten people, and it was in charge of its own budget. This made it possible to effectively combine heritage management responsibilities with actual research (Pelanne 2007).

In 2011, as part of yet another organizational restructuring at the FHA, the Maritime Archaeology Unit was closed and had to leave its maritime environment on Hylkysaari. All tasks related to the protection of underwater cultural heritage were directed to the newly formed Cultural Environment Services. This meant that the maritime archaeology branch of the FHA was no longer in charge of its own budget and instead had to compete for funding with the other branches of the Cultural Environment Services, namely archaeology and restoration and protection of the built environment. This has also led to a situation where large maritime archaeological research projects are increasingly hard to justify, and all larger projects have to be planned with external funding. On the other hand, this organizational change brings experts in many different fields under one roof, which can possibly lead to increased opportunities for organizing multidisciplinary research more efficiently and creatively.

The Antiquities Act remains in effect with minor updates and requires the protection of all underwater sites of ancient origin and wrecks of 100 years of age and older. The FHA is the sole organization in Finland in charge of the protection and management of maritime and underwater cultural heritage, but with the new museum law (314/2019, effective as of 1 January 2020) regional museums have received more responsibility in the management of the cultural heritage in their area in exchange for state funding. This also includes sites of maritime archaeological significance, but what it will do to the research of maritime and underwater heritage remains to be seen. Optimally, it could mean more opportunities within the FHA for maritime archaeological research motivated by other than management responsibilities or public outreach. 


\section{Higher Education in Maritime Archaeology}

Complete degree programmes in archaeology are offered in three universities in Finland: at the University of Oulu in northern Finland, at the University of Turku in western Finland, and at the University of Helsinki in southern Finland. All three universities offer BA, $\mathrm{MA}$, and $\mathrm{PhD}$ degrees with a specialization in archaeology. In terms of research concentration, the University of Helsinki has traditionally specialized in Stone Age and Bronze Age research, whereas research in Turku and Oulu has emphasized Iron Age, medieval, and historical archaeology.

Completing a full specialized degree in maritime archaeology has never been an option in any of the three universities, but larger modules in maritime archaeology have been offered since the early 1990s in Helsinki and Turku. At the University of Helsinki, an interdisciplinary joint module in maritime history, maritime ethnology, and maritime archaeology was initiated in 1993, although teaching within the module was gradually reduced since 2012 and terminated in late 2020. Between 2011 and 2013, the University of Turku offered basic and intermediate-level modules in maritime archaeology as part of its BA or MA degrees in archaeology.

\section{University of Turku}

Archaeology at the University of Turku has a concentration on historical archaeology, and the introduction of maritime archaeology in the program was motivated by an independent field course organized at the seventeenth-century Joskär I wreck in collaboration with the Hanko Summer University since 1998. This field course, which is still organized every year, is targeted at maritime archaeologists and hobby divers alike. Currently, the course is the only platform for university-level training in maritime archaeological field methods in Finland, and due to its focus in field practices, the course has always been quite popular, however much more so among hobby divers than archaeology students.

Due to changes in legislation in Finnish higher education in 2010, teaching at open universities is designed to match the connected university's curriculum. This legislation change was seen as an opportunity to develop teaching in maritime archaeology at the University of Turku. In co-operation with the Hanko Summer University staff, both basic and intermediate-level studies in maritime archaeology were set up at the University of Turku, and a complete module comprising 60 ECTS points was offered between autumn 2011 and spring 2013. In practice, only basic studies were offered during the first two years, with the intent being to attract students to enrol for the intermediate-level courses. The offered courses, taught mainly in Finnish, had a strong focus on underwater archaeology and attracted many participants. As many as 40 students would enrol for the first-year courses and about 15 completed all taught courses (pers. comm. S. Wessman, 22 April 2020). Despite its strong focus on underwater archaeology, diving skills were never required to complete the module.

When a tenure-track professorship in maritime archaeology was announced at the University of Helsinki in 2012, teaching within the same specialized field in Turku was thought redundant for a country as small as Finland, and the last courses were offered in 2013. However, collaboration with Hanko Summer University continues, and it is possible to include the field course as part of one's BA or MA studies in archaeology at the University of Turku (pers. comm. V. Immonen, 6 May 2020). 


\section{University of Helsinki}

In the early 1970s, when the Bureau of Maritime History was the organization responsible for enforcing the 1963 Antiquities Act, a lack of diving archaeologists made implementing these tasks difficult. As in many other parts of the world (e.g., Flatman 2007a, b; Bass 2011; Gately and Benjamin 2018), most of the information about underwater sites was produced with the help of hobbyists and maritime archaeological diving societies. For instance, the Finnish maritime archaeological club Teredo Navalis was established in 1975 to aid the bureau in underwater archaeological research (Konttinen 1991; Talvio 2016, 288), and societies continue to be vital for the discipline in Finland.

Although maritime archaeology courses were organized in Finland for the first time in 1963 (Rosenius 1983, 21), and members of Teredo Navalis, for instance, were trained in maritime archaeological methodology by the FHA (anon 1978), the number of diving researchers was still quite small when Leena Sammallahti became director of the Maritime Museum of Finland in 1988. Upon entering the museum, Sammallahti began to explore the possibilities of establishing training courses for maritime archaeologists at the University of Helsinki and set up a meeting with professors Juhani U.E. Lehtonen (ethnology), Yrjö Kaukiainen (economic history and maritime history), Matti Klinge (history), and Ari Siiriäinen (archaeology). It was decided in the meeting that, within each discipline, lectures in maritime topics would be included in existing teaching and that later those lectures would be combined into an independent study module (pers. comm. L. Sammallahti, 16 April 2020).

The lack of training for diving researchers, then, was the original motivation for setting up teaching at the University of Helsinki, and a module titled Maritime History was established in 1993. The module was 25 ECTS points in total and was taught mainly in Finnish. It consisted of a combined introductory course (8 ECTS) in maritime history, maritime ethnology, and maritime archaeology in which students received an overview of all three fields. Another major part of the module was a practicum (8 ECTS) in maritime history, maritime ethnology, or maritime archaeology. In the practicum, students would learn about research methodology, materials, and sources by working in the archives or in the field. Finally, students were expected to take three book exams ( 9 ECTS in total) on topics related to maritime history,maritime ethnology, and/or maritimearchaeology. The three exams in maritime archaeology focused on research methodology, research materials and sites, and theory of maritime archaeology. The third exam included advanced-level literature on archaeological theory, and, although designed as a basic-level module, in terms of contents it was definitely at the intermediate level (see also Lavento and Ala-Pöllänen 2007).

The Maritime History module was designed to be multidisciplinary from the start, and the development of teaching in maritime archaeology was intimately tied to preexisting teaching in maritime ethnology and maritime history. Maritime historian Yrjö Kaukiainen taught maritime history as part of the curriculum in economic history at the time, which was central to the development - and name-of the module. Leena Sammallahti's background in ethnology further contributed to the interdisciplinary nature of the module. Collaboration with the discipline of biology was also developed, and joint courses with the Department of Hydrobiology were sometimes organized as part of the module. The maritime archaeology component of the module was organized partly with external teaching by Swedish experts, such as Christer Westerdahl and Carl Olof 
Cederlund, but equally important were the Finnish module alumni. Many of those who taught in the module had completed it in its early years.

During its existence, the module, open to all students, was quite popular, with 40-50 students participating in the introductory course in the best years. Of the 40 who took the introductory course, five students on average continued to more advanced and specialized courses in maritime archaeology (pers. comm. A. Ala-Pöllänen, 6 April 2020). Nevertheless, contact teaching in the module reduced dramatically in 2012, and all teaching, including book exams, ended in late 2020. There were three reasons for the module's termination. First, funding for teaching was significantly cut as a result of departmental restructuring within the Faculty of Arts in 2009. Consequently, in its final active years in 2011 and 2012, teaching within the module was only possible with an annual financial support of 10000 $€$ from Nord Stream, the company responsible for constructing a natural gas pipeline in the Baltic Sea between Russia and Europe. As part of the construction, Nord Stream conducted extensive surveys of the natural and cultural environment in the Baltic Sea, and it was in the best interest of the company to develop collaboration with local maritime archaeologists (Matikka 2010). The sponsorship from Nord Stream ended in 2012 with the completion of Nord Stream Line 1, and once the sponsorship had ended so too did contact teaching in the Maritime History module. Secondly, as a result of further organizational restructuring within the University of Helsinki's Faculty of Arts, since 2017 the module has not been part of the teaching plan of the new Department of Cultures. Thirdly, after the tenure-track professorship in maritime archaeology at the University of Helsinki was announced in 2012, teaching responsibilities related to maritime topics were gradually transferred from the Maritime History module to that position.

\section{Fields of Expertise in Underwater Archaeology}

The field of maritime archaeology in Finland is highly interdisciplinary, and people often have experience in both research and heritage management. This is mostly due to the small number of people trained as maritime archaeologists, many of whom have had to assume roles equally in research, teaching, heritage management, and private companies. The fields of expertise of Finnish maritime archaeologists range from medieval and postmedieval shipbuilding, seafaring and related infrastructure to protection and management of underwater cultural heritage and heritage legislation, and from underwater technology and documentation to maritime ethnology.

The majority of people working in maritime archaeology in Finland today, mainly in heritage management, received their training in Finland, and many studied and taught in the University of Helsinki's Maritime History module. Some received their training or part of it abroad (Sweden, Denmark, and the UK). Worth mentioning is also the now discontinued scientific diving training that began in Finland in 1995, a program that many Finnish maritime archaeologists completed (see also Länne 2005). More importantly, however, maritime archaeologists who studied maritime history in Helsinki and graduated in the 1990 and 2000s received their field training on underwater operations organized since the early 1990s as collaborative research projectsbetween the Bureau of Maritime History (i.e., FHA) and hobby divers. Thus, it is not surprising that the underwater archaeological research organized by the FHA since the late 1980s became central to the development of the field as well as to the identity of individual researchers. In this respect, such shipwrecks 
as the Mulan wreck, Kronprins Gustav Adolf and Vrouw Maria, which were studied consecutively by the FHA from 1988 to 2012, are of central importance.

The Mulan wreck in Hanko had been known among divers since the 1970s, but it was only reported to the FHA in 1987 and excavated between 1988 and 1995 (Sammallahti 1990, 1991; Heporauta 1991; Sievänen 2000). The ship itself is about $12 \mathrm{~m}$ in length, clinker-built, and foundered most likely in the early seventeenth century. The Mulan wreck has played a key role in the development of Finnish maritime archaeology because it served as a site for training in field methods for a host of Finnish maritime archaeologists. In most years, the research was led by the director of the Maritime Museum of Finland, Leena Sammallahti. The majority of the diving was done by members of Teredo Navalis, but the excavations also saw the formation of a group of diving researchers, such as art historian Arne Heporauta (later Hästesko), maritime archaeologist Riikka Alvik, and maritime ethnologist Sallamaria Tikkanen.

The wreck of the late eighteenth-century Swedish ship Kronprins Gustaf Adolf was discovered in 1995 and excavated between 1997 and 1999 (Tikkanen 2000). A host of maritime archaeologists and heritage professionals active in Finland today worked as researchers at the excavations. Teredo Navalis was again also involved in the excavations. In 2000, the wreck was turned into an underwater park, the first of its kind in the Baltic Sea, and similar parks have since opened in, for instance, Hanko and Kirkkonummi (see Leino and Flinkman 2012; for early plans to set up underwater parks in Finland, see also Tikkanen 1997).

Of the approximately 2200 underwater sites listed in the FHA registry of ancient sites and monuments, the wreck of Vrouw Maria has undoubtedly been the most extensively researched and attracted the most media attention. The well-preserved remains of the eighteenth-century Dutch merchant ship were discovered in 1999 by Pro Vrouw Maria, a society established for the sole purpose of locating the wreck (Ahlström 2000; Saure 2009). Vrouw Maria has been researched since 2000 (Laitinen 2000; Leino 2002), primarily during two large research projects. The first was the EU-funded MoSS (Monitoring, Safeguarding and Visualizing North-European Shipwreck Sites) project, which ran from 2001 to 2004 (Leino 2003, 2004; MoSS 2005; FHA 2007; Leino et al. 2011). The second was the Vrouw Maria Under Water project, funded by the Ministry of Education. This research project ran between 2009 and 2012, and it continues to result in publications related to the wreck (e.g., Alvik and Matikka 2011; Ehanti et al. 2012; FHA 2014; Leinonen 2016; Alvik 2019; Lempiäinen-Avci et al. 2021).

Many Finnish maritime archaeologists worked with Vrouw Maria, and volunteer divers from Teredo Navalis and Pro Vrouw Maria participated in the underwater activities. Salvage of Vrouw Maria was planned since its discovery (Halinen 2000). The most promising discussions took place with Russian experts in 2007-2009, but those did not lead to any concrete action. Total costs, including raising, conservation, and the establishment of a dedicated museum, were at that time calculated at 80-100 million euros (FHA 2014, 14). The prospect of raising and exhibiting Vrouw Maria undoubtedly sparked hope that Finland could finally have a museum built around a preserved historical ship, just like Norway and Denmark have done for various Viking ships and Sweden for Vasa, the ship that gave much of the impetus for the development of the field also in Finland.

In terms of significant wrecks relevant for the development of Finnish maritime archaeology, the Joskär 1 wreck, located in Hanko, and first reported to the FHA by marine geologist Boris Winterhalter in 1962, is also worthy of mention. This seventeenth-century wreck has been documented and excavated since the 1980s, and research has mainly taken place in form of a field course organized by the Hanko Summer University since 1998, which 
is why the wreck has been important for the dissemination of knowledge and the development of collaboration between maritime archaeologists and hobby divers (unpublished research reports in the FHA archives).

While the research projects listed in the course of our historical outline of Finnish maritime archaeology were almost exclusively organized by the FHA, and by maritime archaeologists who received their field training during those projects, the role of hobby divers and diving societies has always been equally important. Hobbyists have an active role as facilitators of scientific research at and around known wrecks and in locating new ones. For instance, the Finnish Maritime Archaeological Society (MAS), established in 1995, has been an active promoter of maritime archaeological research in Finland. Since 2018, MAS has developed the Porkkala Wreck Park in Kirkkonummi. The park area contains possibly dozens of wrecks from the sixteenth century to the nineteenth century, four of which have been documented by MAS, which also manages the infrastructure, such as guidelines with information boards, that makes it possible to explore the wrecks.

In recent years, the wrecks in the Porkkala park have also been sampled for dating and other scientific analyses, and the collection of samples has been done by MAS volunteers. MAS also organizes maritime archaeological training, such as Nautical Archaeology Society (NAS) training courses and training in underwater photogrammetry. These three areas, the developing of wreck parks, facilitating of research projects, and organizing of training, have been a growing point of focus for MAS in recent years, and the number of members tends to follow the amount of organized activities (pers. comm. M. Luoto, 25 August 2020). Due to their central role, organizations such as MAS, as well as the avocational diving societies that provide many of the volunteer divers, should be included when writing a history of Finnish maritime archaeology and also when discussing the present state of expertise in and the future of the field.

\section{Future Tasks in Finnish Maritime Archaeology}

During the 50 plus years of maritime archaeological research in Finland, a field has developed with a great deal of expertise in maritime archaeology, underwater/maritime heritage management, and public outreach. The great majority of Finnish experts work in heritage management, but research within that organization has, for obvious reasons, been motivated by public outreach and the protection of underwater cultural heritage. Furthermore, with the changes that took place in maritime heritage management as result of the organizational changes and the termination of the Maritime Archaeology Unit in 2011, it has become challenging to justify large archaeological research projects at the FHA economically. Underwater excavations motivated by research rather than rescue, for instance, are extremely rare today. Instead, large collaborative projects like the EU-funded BALTACAR (Baltic History Beneath Surface: Underwater Heritage Trails in situ and Online) (Roio 2019) or BalticRIM (Baltic Sea Region Integrated Maritime Cultural Heritage Management) are targeted at promoting diving on the wrecks or more efficient planning of the use of the Baltic Sea areas, respectively.

The intertwined history of Finnish heritage management, academic training, and the avocational sector also means that there is a heavy research concentration on underwater heritage in the coastal areas dating to the historical period. There exist specific reasons for this focus. Of the underwater sites listed in the Finnish registry of archaeological sites approximately $77 \%$ are wrecks or parts of wrecks from the historical period (FHA 2019, 
47). Because hobbyists often share an interest in the well-preserved wrecks from the seventeenth and eighteenth centuries, research conducted at the FHA has aimed at providing knowledge that benefits the general publicwhile safeguarding the protection of the sites. Another related reason is that academic maritime archaeological training in Finland has emphasised historical research. The maritime archaeology curriculum at the University of Turku was designed to fit the historical research concentration of their archaeology program. The Maritime History module at the University of Helsinki on the other hand was built on existing teaching in maritime history and maritime ethnology. Keeping in mind that practically all active maritime archaeologists in Finland received their training at least partly in Helsinki or Turku, the focus on underwater sites dating to the historical period is hardly surprising.

This is not to deny that research has not been conducted on topics other than historical wrecks, and often by the same people. Heritage management at the FHA would not be possible without acknowledging that underwater cultural heritage makes up only part of the research areas, and that maritime cultural heritage includes much more than what remains underwater. At the same time, however, in their overview of the state of maritime cultural heritage, the FHA $(2019,44)$ acknowledges that there are severe gaps in knowledge when it comes to understanding the overall geographical, thematic, and temporal scope of maritime cultural heritage in the country. The FHA defines the term maritime cultural heritage widely to include also sites in riverine and lake environments, areas that remain particularly poorly understood in terms of cultural heritage.

Maritime archaeological research of lake areas, wetlands, or coastal landscapes, for instance, have been few, and instead conducted at universities rather than at the FHA. One example of maritime cultural landscape research is the Our Maritime Heritage project at the University of Helsinki (2002-2005) during which circa 450 new sites from the Late Iron Age and Early Middle Ages were found and documented in the coastal areas of Uusimaa in southern Finland (Jansson 2005). Another example is the Settlements and Economies Around the Sea-Maritime Settlement, Subsistence and Economic Histories Around the Baltic Sea 500-1700 AD project which ran at the University of Helsinki between 2009 and 2012 (e.g., Haggrén and Lavento 2011; Alenius et al. 2014). The Lost Inland Landscapes (2015-2018) project on the other hand concentrated explicitly on the Mesolithic and Early Neolithic wetland and shoreline dwelling sites in the lake Saimaa area in central Finland. While drawing from an earlier project, Lost Inland Landscapes was the first to draw attention to the huge research potential of inundated inland sites (Koivisto 2017; Groß et al. 2018).

The lake and wetland areas of inland Finland remain relatively poorly understood regardless of temporal focus, and we see those as areas where many of the future tasks of Finnish maritime and underwater archaeology lie. Stone Age rock paintings, for example, are situated along ancient waterways and may still hold a lot of potential for maritime archaeological research (e.g., Grönhagen 1991; Taskinen 2006; Lahelma 2012). Another group of archaeological sites and materials of interest is those belonging to the historical period. Despite the long history of ethnological and archaeological research on boat building (e.g., Itkonen 1942; Forssell 1985; Taavitsainen 1999), very little is known about river and lakeside portages, for instance.

Knowledge of sites in inland areas will most likely increase in the future as a result of the ongoing Nationally Significant Archaeological Sites project at the FHA. The purpose of the project, which will be completed in 2022, is to provide an overview of the antiquity of Finland in terms of important sites, including sites of maritime archaeological relevance. Another likely positive development is the new museum law which gives regional 
museums more responsibilities in the management of their local cultural heritage, but also more accountability in terms of accessibility and public outreach. This could potentially lead to more detailed surveys and knowledge of the cultural heritage of inland areas, but ideally also to increased awareness of the maritime archaeological heritage of the region among hobby divers.

\section{Conclusion}

The purpose of our exposition of the early as well as recent history of Finnish maritime archaeology in this article has been to highlight the interconnectedness of the heritage management sector, academically trained maritime archaeologists, and avocational diving societies and volunteers. Based on our offered historiography, we also gave concrete suggestions as to where the future directions of the discipline lie in the country. In terms of research focus, Finnish maritime archaeology has been and continues to be heavily underwater-oriented and focussed on nautical material. This is partly due to the connected history of maritime archaeological research and heritage management and the abundance of well-preserved wrecks from the historical period in the Baltic Sea. Regardless of this concentration, research, especially that of shipwrecks, has been extremely interdisciplinary, connecting history, ethnology, archaeology, heritage studies, and the natural sciences. The interdisciplinarity of Finnish maritime archaeology provides a fertile ground for thematic expansion within the discipline in the future. We see the study of inland areas in particular to hold much potential, regardless of the temporal concentration of future research.

Research diversity is naturally dependent on research infrastructures, and on the positive side, the potential for securing maritime archaeological research opportunities in Finland is slowly increasing. We discussed above some recent and ongoing changes that may have a positive impact on the heritage management sector, such as the increasing responsibility of regional museums with the new museum law. In terms of training and higher education, on the other hand, significant progress is likewise to be expected in the near future. Secured funding exists for the establishment of Finnish Scientific Diving Academy at the University of Helsinki, a new institute which, once up and running, would provide much-needed field training for future underwater archaeologists.

Furthermore, courses in maritime archaeology are currently offered at the University of Helsinki and teaching is being actively developed. We have offered elsewhere an in-depth analysis of the factors to consider in the planning of teaching (Marila and Ilves 2020). Our findings indicate that integration should be sought with other disciplines, especially archaeology and heritage studies, but also with maritime programs in other universities. In order to successfully anticipate the varying needs of the field, the FHA and the avocational and private sectors should likewise be included in curriculum design. More importantly, however, the long-term continuity of teaching should be secured. The key finding of our research was that maritime archaeology degree programs often have very few staff and become discontinued with leaving or retirement of staff members (Marila and Ilves 2020). It is therefore crucial, especially in light of the discontinuities that have taken place in teaching of maritime archaeology at the University of Turku and at the University of Helsinki that both teaching and research are planned with long-term continuity in mind, and that thematic diversity is sought through integration with other disciplines.

Acknowledgements For this research, we interviewed 15 retired as well as presently active individuals in Finnish academic maritime archaeology, maritime and underwater heritage management, and the 
avocational sector-we are grateful for their trust and willingness to share their memories, recollections, and perspectives. We also thank Riikka Alvik, Minna Koivikko, Wesa Perttola, Kalle Virtanen, Veronica Walker-Vadillo, and the reviewers for their comments on earlier versions of the text. All factual errors remain ours alone.

Authors' contributions Both authors claim equal ownership of the contribution.

Funding Open access funding provided by University of Helsinki including Helsinki University Central Hospital. The research was supported by the Weisell Foundation.

\section{Declarations}

Conflict of interest The authors report no conflicts of interest.

Open Access This article is licensed under a Creative Commons Attribution 4.0 International License, which permits use, sharing, adaptation, distribution and reproduction in any medium or format, as long as you give appropriate credit to the original author(s) and the source, provide a link to the Creative Commons licence, and indicate if changes were made. The images or other third party material in this article are included in the article's Creative Commons licence, unless indicated otherwise in a credit line to the material. If material is not included in the article's Creative Commons licence and your intended use is not permitted by statutory regulation or exceeds the permitted use, you will need to obtain permission directly from the copyright holder. To view a copy of this licence, visit http://creativecommons.org/licenses/by/4.0/.

\section{References}

Aartomaa J (2008) Merikeskus Vellamo_kohtaamispaikka Kotkan satamassa. 9.7.2008. Finnish Heritage Agency/City of Kotka, Helsinki

Ahlström C (1978) Documentary research on the Baltic. Three case studies. Int J Naut Archaeol 7:59-70

Ahlström C (2000) The Russian Empress and the Dutch kof-ship Vrouw Maria. Nautica Fennica 2000:13-16

Alenius T, Haggrén G, Oinonen M, Ojala A, Pitkänen R-L (2014) The history of settlement on the coastal mainland in Southern Finland: Palaeoecological, archaeological, and etymological evidence from Lohjansaari Island, Western Uusimaa, Finland. J Archaeol Science 47:99-112

Alvik R (2013) Things on board. The interpretation of three 18th century shipwrecks from the Gulf of Finland. In: Adams J, Rönnby J (eds) Interpreting shipwrecks. Maritime archaeological approaches. Highfield Press, Southampton, pp 119-126

Alvik R (2019) Wreck of the Dutch merchant ship Vrouw Maria: example of protection and management of underwater cultural heritage in Baltic waters. In: Campbell S, White L, Thomas S (eds) Competing values in archaeological heritage. Springer, Cham, pp 7-24

Alvik R, Matikka M (2011) The wreck of Vrouw Maria-problems and good practices in the protection of underwater sites. In: Ramskjaer L, Nyhamar A, Chabiera A, Aniszewski M (eds) Stop heritage crime. Good practices and recommendations. National Heritage Board of Poland, Warsaw, pp 149-152

anon (1978) New diving assistant trained, the Maritime Museum Helsinki. The Maritime Museum Helsinki Annual Report 1978:19

Barstad JF (2002) Underwater archaeology in the 20th century. Filling in the gaps. In: Ruppé CV, Barstad JF (eds) International handbook of underwater archaeology. Kluwer, New York, pp 3-16

Bass GF (2011) The development of maritime archaeology. In: Ford B, Hamilton DL, Catsambis A (eds) The oxford handbook of maritime archaeology. Oxford University Press, Oxford, pp 3-22

Broadwater JD (2002) Timelines of underwater archaeology. In: Ruppé CV, Barstad JF (eds) International handbook of underwater archaeology. Kluwer, New York, pp 17-24

Cleve N (1961) Kulturhistorisk forskning på havsbotten. Finsk Tidskrift 8/1961:349-354

Cleve N (1976) Merimuseo tulossa. Nautica Fennica 1:8-13

Delgado JP (2000) Underwater archaeology at the dawn of the 21st century. Hist Archaeol 34:9-31

Ehanti E, Aartomaa J, Lounatvuori I, Tirkkonen E (2012) Lost at sea, rediscovered. Finnish Heritage Agency, Helsinki

Ericsson CH (1970) Technical. In: Bureau of Maritime Archaeology (ed) Report April 1970. A brief description of underwater work carried out by the Bureau of Maritime Archaeology in collaboration 
with skindivers of various local clubs belonging to the Federation of Finnish Skindivers. Finnish Heritage Agency, Helsinki, pp 7-9

Ericsson CH (1972) A sunken Russian frigate. Archaeol 25:172-179

Ericsson CH (1975) The instruments from Her Imperial Majesty's frigate Nicholas. Int J Naut Archaeol $4: 65-71$

Ericsson CH, Halme R (1971) St Nicholas exhibition, covering 20 years of looting and research. In: Bureau of Maritime Archaeology (ed) Report December 1971. A description of underwater work carried out by the Bureau of Maritime Archaeology and other institutions within territorial waters of Finland. Finnish Heritage Agency, Helsinki, p 2

Fast M (1996) A maritime museum on a pilot station island in the centre of Helsinki. Nautica Fennica 1996:38-51

FHA (2007) Vrouw Maria-Selvitys tutkimuksista, tuloksista ja tulevaisuuden eri vaihtoehdoista. Finnish Heritage Agency, Helsinki

FHA (2014) Vrouw Maria veden alla -hankkeen 2009-2012 loppuraportti. Finnish Heritage Agency, Helsinki

FHA (2019) Suomen merellisen kulttuuriperinnön tilannekuvaus. Finnish Heritage Agency, Helsinki

Flatman J (2007a) The origins and ethics of maritime archaeology. Publ Archaeol 6:77-97

Flatman J (2007b) The origins and ethics of maritime archaeology. Part II. Publ Archaeol 6:163-176

Forssell H (1985) The reconstruction of a sewn boat find from lake Mekrijärvi. World Archaeol 16(3):304-311

Gately I, Benjamin J (2018) Archaeology hijacked: addressing the historical misappropriations of maritime and underwater archaeology. J Marit Archaeol 13:15-35

Groß D et al (2018) People, lakes and seashores: studies from the Baltic Sea basin and adjacent areas in the early and mid-Holocene. Quatern Sci Rev 185:27-40

Grönhagen J (1991) Järviarkeologiaa Saimaalla - meripihkalöytö Ristiinan Astuvansalmelta. The Maritime Museum of Finland Annual Report 1991:78-83

Haggrén G, Lavento M (2011) Preface. In: Haggren G, Lavento M (eds) Maritime landscape in change. Archaeological, historical, palaeoecological and geological studies on Western Uusimaa. Finnish Antiquarian Society, Helsinki, pp 4-8

Halinen P (2000) Vrouw Maria. Muinaistutkija 1/2000:59-62

Halme R (1976) On the protection of underwater antiquarian sites in Finland. The Maritime Museum Helsinki Annual Report 1976:8-9

Halme R (1977) The kitchen area of the frigate Nicholas. The Maritime Museum Helsinki Annual Report 1977:17-19

Heikkinen H (1976) Merimuseotoiminta. Nautica Fennica 1:30-36

Heporauta A (1991) The Mulan wreck: what type of vessel was it? The Maritime Museum of Finland Annual Report 1991:58-61

Hyvärinen T, Sammallahti L (1991) Hylkysaari Island-Home of the Maritime Museum of Finland. The Maritime Museum of Finland Annual Report 1991:16-21

Hyvönen H (1997) The St. Mikael and Meissen porcelain. Nautica Fennica 1997:50-55

Immonen V (2016) Tutkimuksen ja hallinnon ristiaallokossa-2: Muinaistieteellinen toimikunta 1917-1972. Museoviraston julkaisuja 3. Finnish Heritage Agency, Helsinki

Immonen V, Taavitsainen J-P (2011) Oscillating between national and international: the case of Finnish archaeology. In: Lozny LR (ed) Comparative archaeologies. A sociological view of the science of the past. Springer, New York, pp 137-177

Itkonen TI (1942) Suomen ruuhet. 1-, 2-, 3- ja monipuiset sekä lautaruuhet kivikaudesta vuoteen 1940. Finnish Antiquarian Society, Helsinki

Jansson H (2005) Merellinen perintömme. Vårt maritima arv. CD Rom. University of Helsinki, Helsinki

Johnsson R (1988) Hiljaiset laivat—sukelluksia menneisyyteen. Suomen urheilusukeltajien liitto, Helsinki

Kaukiainen Y (2020) Borstön hylky ei ollutkaan S:t Mikael. Nautica Fennica 2020:12-27

Koistinen P (1976) Suomen merihistoriallinen seura ry. Nautica Fennica 1:6-7

Koivikko M (2017) Recycling ships. Maritime archaeology of the UNESCO world heritage site, Suomenlinna. Dissertation, University of Helsinki

Koivisto S (2017) Archaeology of Finnish wetlands, with special reference to studies of Stone Age stationary wooden fishing structures. Dissertation, University of Helsinki

Konttinen H (1991) Teredo Navalis Ry. Historia vuoteen 1990. Teredo Navalis, Helsinki

Lahelma A (2012) Sukellustutkimukset Iitin Kotojärven kalliomaalauksen edustalla. In: Niinimäki S, Salmi A-K, Kuusela J-M, Okkonen J (eds) Stones, bones \& thoughts. Festschrift in honour of Milton Nuñez. Oulu, pp 88-100

Laitinen M (2000) Vrouw Maria -hylky ja 1700-luvun hollantilaiset purjealustyypit kirjallisissa lähteissä. SKAS 4/2000:16-23 
Lavento M, Ala-Pöllänen A (2007) Näkymiä meriarkeologian opetukseen ja tutkimukseen Helsingin yliopistossa—mitä Bolognan prosessin jälkeen? ICOMOS—Suomen osaston jäsentiedote 4/2007:14-19

Leino M (2002) Nauvo, Trunsjö: Vrouw Maria -hylky—raportti hylyn kenttätutkimuksista 2000. Finnish Heritage Agency, Helsinki

Leino M (2003) Nauvo, Trunsjö: Vrouw Maria -hylky—raportti hylyn kenttätutkimuksista 2001. Finnish Heritage Agency, Helsinki

Leino M (2004) Nauvo, Trunsjö: Vrouw Maria -hylky—raportti hylyn kenttätutkimuksista. Finnish Heritage Agency, Helsinki

Leino M, Flinkman J (2012) A ship at the bottom of the sea is a wreck. From environmental problem to common source of enjoyment. Nautica Fennica 2011-2012:44-55

Leino M, Ruuskanen AT, Flinkman J, Kaasinen J, Klemelä UE, Hietala R, Nappu N (2011) The natural environment of the shipwreck Vrouw Maria (1771) in the northern Baltic Sea: an assessment of her state of preservation. Int J Naut Archaeol 27:133-150

Leinonen A (2016) Symboliikkaa purjelaiva Vrouw Marian koristereliefeissä. In: Niukkanen M, Pesonen P, Alvik R (eds) Monttu auki. Arkeologisia kenttätutkimuksia 1. Finnish Heritage Agency, Helsinki, pp 140-147

Lempiäinen-Avci M, Timonen T, Harju P, Alvik R (2021) Underwater archaeobotany: plant and wood analyses from the Vrouw Maria, a 1771 shipwreck in the Finnish Baltic Sea. Vegetation History Archaeobotany. https://doi.org/10.1007/s00334-021-00840-3

Länne P (2005) 10 vuotta ammatillista sukelluskoulutusta ja näyttötutkintoja—juhlajulkaisu. Innofocus LänsiUudenmaan aikuiskoulutuskeskus, Nummela

Marila M, Ilves K (2020) Long-term degree program success in maritime archaeology. University of Helsinki, Helsinki

Matikka M (2010) Historia kohtaa nykypäivän kaasuputkilinjauksella. Museo 2/2010:14-15

Mattsson R (1990) The Frigate sunk in the battle of Ruotsinsalmi and some facts revealed by Russian history. The Maritime Museum of Finland Annual Report 1989-1990:29-34

Ministry of Education (2004) Suomen merimuseon siirtyminen Kotkaan. Ministry of Education, Helsinki

MoSS (2005) Monitoring, safeguarding and visualizing North-European shipwreck sites: common European cultural heritage_-challenges for cultural resource management. Final report. Finnish Heritage Agency, Helsinki

Nurmio-Lahdenmäki A (2005) S:t Mikael 1747. Fingrid, Jyväskylä

Patoharju O (1962) Meriarkeologiaa muualla ja meillä. Valvoja 5:263-272

Patoharju O (1965) Corrosion Problems in Marine Archaeology. In: Larinkari J (ed) Current corrosion research in Scandinavia: lectures held at the 4th Scandinavian Corrosion Congress (NKM) November 24-27, 1964, Helsinki. Kemian Keskusliitto ry, Helsinki, pp 316-323

Patoharju O (1975) Conservation of cannon recovered from the Brackish Sea. Stud Conserv 20:183-187

Pelanne M (2007) Meriarkeologian yksikkö. ICOMOS—Suomen osaston jäsentiedote 4/2007:20-22

Peltonen J (1964) Vedenalaista arkeologiaamme-ja sen luomia kulttuurihistoriallisia näkymiä. Osma 1962-1963:84-99

Roio M (2019) Baltic History Beneath Surface. National Heritage Board of Estonia, Tallinn

Rosenius H (1968) Fregatten Nikolaj. Marinarkeologisk experimentfält och varnande exempel. Nordenskiöldsamfundets tidskrift 1968:55-68

Rosenius H (1983) Meriarkeologian alkuvaiheista Suomessa. Nautica Fennica 2:16-22

Sammallahti L (1990) Investigations by the Maritime Museum of Finland on the Mulan wreck in Hanko. The Maritime Museum of Finland Annual Report 1989-1990:64-73

Sammallahti L (1991) The Mulan wreck in Hanko: the wreck site and some of the finds. The Maritime Museum of Finland Annual Report 1991:73-77

Sarvas P (1977) Coins from the frigate Nicholas. The Maritime Museum Helsinki Annual Report 1977:10-13

Saure H (2009) Aarrelaivojen jäljillä. Rauno Koivusaaren meriseikkailuja. Otava, Helsinki

Sievänen M (2000) Pistols from the 17th century wreck of Mulan. Nautica Fennica 2000:30-31

Sorvali H (1977) On the design and dimensions of the frigate Nicholas. The Maritime Museum Helsinki Annual Report 1977:13-16

Suhonen M (2009) Maakrapu merikeskuksessa—vasta-avatun Vellamon taustaa ja tunnelmia. Muinaistutkija 1/2009:2-10

Taavitsainen J-P (1999) Wilderness commerce and the development of boat types. The remains of the Hartola boat. In: Huurre M (ed) Dig it all: papers dedicated to Ari Siiriäinen. Finnish Antiquarian Society, Helsinki, pp 308-313

Talvio T (2016) Ikkuna menneeseen ja tulevaan—2: Suomen kansallismuseo. Museoviraston julkaisuja 7. Finnish Heritage Agency, Helsinki 
Taskinen H (2006) Rock painting sites in Finland: Archaeological excavations and underwater investigations. Adoranten 2006:19-27

Tikkanen S (1997) Inspection dives by The Maritime Museum of Finland in 1996. Nautica Fennica 1997:65-69

Tikkanen S (2000) The ship of the line Kronprins Gustaf Adolf-a Swedish warship wrecked in 1788. Nautica Fennica 2000:69-89

Tuovinen T (2002) The burial cairns and the landscape in the archipelago of Aboland, SW Finland, in the Bronze Age and the Iron Age. Dissertation, University of Oulu

Utriainen A (2010) Maritime Centre Vellamo. Finnish Heritage Agency/City of Kotka, Helsinki

Publisher's Note Springer Nature remains neutral with regard to jurisdictional claims in published maps and institutional affiliations. 